\title{
Effectiveness of Adding Extruded Wheat Straw to Poultry Manure to Increase the Rate of Biogas Yield
}

\author{
Polishchuk V.M. ${ }^{1}$, Shvorov S.A. ${ }^{1}$, Zablodskiy M.M. ${ }^{1}$, Kucheruk P.P. ${ }^{2}$, \\ Davidenko T.S. ${ }^{1}$, and Dvornyk Ye.O. ${ }^{1}$
}

\author{
${ }^{1}$ National University of Life and Environmental Sciences of Ukraine, Kyiv, Ukraine \\ ${ }^{2}$ Institute of Engineering Thermophysics of National Academy of Sciences of Ukraine, Kyiv, \\ Ukraine
}

\begin{abstract}
The work is aimed at increasing the biogas yield rate at biogas plants by means of codigestion poultry manure in combination with extruded wheat straw. To achieve this goal a series of batch tests were performed to study the yields of biogas and $\mathrm{CH}_{4}$ in anaerobic fermentation of mixtures of manure with extruded wheat straw. The working hypothesis of the study was that the wheat straw addition would allow optimizing carbon to nitrogen ratio reducing thus the inhibitory effect of ammonium nitrogen contained in poultry manure on the digestion process. The most important result of the study consisted in the development of a methodology for determining the efficient ratios of extruded straw to poultry manure, at which the highest rate of methane yield was ensured. The two series of the batch assays at $36^{\circ} \mathrm{C}$ were performed to study the effect of the straw addition to chicken manure at high and low initial volatile solids concentrations. In each series, three types of mixtures were prepared - with $100 \%, 65 \%$ and $35 \%$ of poultry manure by volatile solids content in the combination with wheat straw pellets. The significance of the research results was in the fact that the use of extruded straw together with chicken manure could increase the rate of methane yield by almost two times, compared to the fermentation of only poultry manure. The positive effect of wheat straw addition to poultry manure was found in mixtures with a high initial volatile solids concentration, and hence, a high concentration of nitrogen.
\end{abstract}

Keywords: biogas, substrate, chicken droppings, straw, dry organic matter, digester, biogas plant, methane fermentation.

DOI: https://doi.org/10.52254/1857-0070.2021.3-51.10

UDC: 662.763.3.2

\section{Eficiența adăugării paiului de grâu extrudat la gunoiul de pasăre pentru creșterea ratei de producție a biogazului}

${ }^{1}$ Polisciuk V.N., ${ }^{1}$ Șvorov S.A., ${ }^{1}$ Sablodski N.N., ${ }^{2}$ Kuceruk P.P., ${ }^{1}$ Davidenko T.S., ${ }^{1}$ Dvornik E.A.

${ }^{1}$ Universutatea Națională a resurselor bioligice li utilizarea naturii Ucrainei, Kyev, Ucraina

${ }^{2}$ Institutl de termofizică tehnică Academiei Națională a științei Ucrainei, Kyev, Ucraina

Rezumat. Scopul lucrării este de a crește randamentul de biogaz în plantele de biogaz datorită fermentării comune a gunoiului de pasăre cu paie de grâu extrudată. Pentru a atinge acest obiectiv, au fost rezolvate următoarele sarcini: a fost dezvoltată o abordare metodologică pentru efectuarea cercetărilor; analiza compoziției fizice și chimice a inoculului și a probelor de materiale organice; modelarea compoziției componente a unui amestec de inocul și probe de testare a materialelor organice; au fost investigați experimental indicatorii producției de biogaz și CH4 în procesul de fermentare anaerobă periodică a amestecurilor de gunoi de grajd cu paie de grâu extrudată. Ipoteza de lucru a studiului este că adăugarea paiului de grâu va optimiza raportul C: N, reducând astfel efectul inhibitor al azotului de amoniac din gunoiul de pasăre asupra fermentației. Cel mai important rezultat al studiului este dezvoltarea unei metodologii pentru determinarea raporturilor raționale ale paiului extras şi a gunoiului de grajd, la care se asigură cea mai mare rată de eliberare de metan. Semnificația rezultatelor cercetării constă în faptul că utilizarea paiului extrudat împreună cu excrementele de pui poate crește rata de eliberare a metanului de aproape 2 ori, comparativ cu fermentarea numai a excrementelor de pasăre. Avantajul utilizării peletelor din paie de grâu extrudat este, de asemenea, că astfel de materii prime sunt mai bine transportate și depozitate într-un depozit, ceea ce este necesar pentru funcționarea continuă a instalațiilor de biogaz, deoarece deșeurile agricole sunt sezoniere.

Cuvinte-cheie: biogaz, substrat, gunoi de grajd, paie, materie organică uscată, fermentator, plantă de biogaz, fermentare cu metan. 
Эффективность добавления экструдированной соломы пшеницы к куриному помету для увеличения скорости выхода биогаза

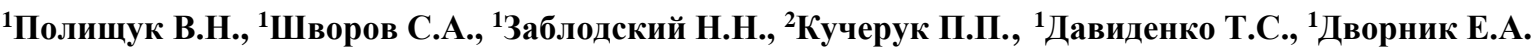

${ }^{1}$ Национальный университет биоресурсов и природопользования Украины, Киев, Украина

${ }^{2}$ Институт технической теплофизики Национальной академии наук Украины, Киев, Украина

Аннотация. Целью работы является повышение выхода биогаза на биогазовых установках за счет совместного сбраживания птичьего помета с экструдированной соломой пшеницы. Для достижения поставленной цели решались следующие задачи: разработан методический подход для проведения исследований; проведен анализ физико-химического состава инокулята и образцов органических материалов; произведено моделирование компонентного состава смеси инокулята и исследуемых образцов органических материалов; экспериментально исследованы показатели выхода биогаза и $\mathrm{CH}_{4}$ в процессе периодического анаэробного сбраживания смесей помета с экструдированной соломой пшеницы. Рабочая гипотеза исследования заключается в том, что добавление пшеничной соломы позволит оптимизировать соотношение $\mathrm{C}: \mathrm{N}$, уменьшив таким образом ингибирующее воздействие аммонийного азота, содержащегося в птичьем помете, на процесс сбраживания. Наиболее важный результат исследования заключается в разработке методики определения рациональных соотношений экструдированной соломы и помета, при которых обеспечивается наибольшая скорость выхода метана. Для изучения эффекта добавления соломы в куриный помет были проведены две серии экспериментов в периодическом режиме при температуре $36^{\circ} \mathrm{C}-$ с высокой и низкой исходной концентрации органического вещества. В каждой серии испытывались три вида смесей - $100 \%, 65 \%$ и $35 \%$ птичьего помета (по сухому органическому веществу) в сочетании с гранулами из пшеничной соломы. Значимость результатов исследования состоит в том, что использование экструдированной соломы совместно с куриным пометом позволяет увеличить скорость выхода метана почти в 2 раза, по сравнению со сбраживанием только птичьего помета. Преимущество использования гранул из экструдированной пшеничной соломы состоит также в том, что такое сырье лучше транспортировать и хранить на складе, что необходимо для непрерывной работы биогазовых установок, так как сельскохозяйственные отходы являются сезонными.

Ключевые слова: биогаз, субстрат, куриный помет, солома, сухое органическое вещество, ферментер, завод по производству биогаза, метановое брожение.

\section{СПИСОК СОКРАЩЕНИЙ}

ПК - помет куриный; СВ - сухое вещество; СОВ - сухое органическое вещество; ПСП пеллеты соломы пшеницы; ХПК - химическое потребление кислорода; VS - летучее твердое вещество.

\section{ВВЕДЕНИЕ}

Современное птицеводство сталкивается с огромным количеством энергетических и экологических проблем. Птичий помет, в результате его накапливания, является потенциальным источником возникновения экологического неблагополучия не только на птицефабриках, но и для экосистемы. При хранении помета может выделяться как метан, так и окись азота, имеющие влияние на парниковый эффект в десятки раз сильнее, чем $\mathrm{CO}_{2}$. С другой стороны, птичий помет совместно с другими отходами сельского хозяйства можно эффективно утилизировать путем анаэробного сбраживания в биогазовых установках, получая при этом биогаз, электрическую и тепловую энергию, ценное органическое удобрение, а также снижать при этом выбросы парниковых газов.

Эффективная технология производства биогаза из отходов животноводства и птицеводства предусматривает использование дополнительных видов сырья, что позволяет увеличивать мощность отдельных биогазовых заводов, а также оптимизировать и стабилизировать технологический процесс выработки биогаза. Одним из самых перспективных видов такого дополнительного сырья является побочная продукция растениеводства (солома и стебли колосовых культур, кукурузы, и тому подобное). Однако, на сегодняшний день не достаточно полно изучены вопросы эффективной совместной переработки отходов птицеводства и растениеводства путем их сбраживания в биогазовых установках с целью повышения выхода биогаза и производных энергоресурсов (тепла, электроэнергии, биометана), снижения выбросов парниковых газов, что является актуальной научно-технической задачей.

\section{І. ПОСТАНОВКА ЗАДАЧИ}

При кормлении птицы энергия 
растительных кормов не полностью усваивается, и большая ее часть переходит в помет. Органическое вещество сырого помета нестабильно и склонно разлагаться в естественных условиях с выделением метана и окиси азота. Для помета характерно значительное содержание белка, который является источником N. При этом отношение $\mathrm{C}: \mathrm{N}$ меньше оптимального, что приводит к образованию аммиака, при определенной концентрации которого наблюдается ингибирование процесса метанового сбраживания.

Вследствие высокой концентрации азота и низкого соотношения $\mathrm{C}: \mathrm{N}$, помет, как моносубстрат, не очень хорошо подходит для анаэробного сбраживания. Оптимизация процесса сбраживания помета предусматривает либо удаление избыточного азота, либо снижения его концентрации путем добавления веществ с более высоким соотношением $\mathrm{C}: \mathrm{N}$. Это позволяет стабилизировать процесс брожения за счет снижения вредного воздействия аммиака на метанобразующие бактерии.

Одним из наиболее значимых органических материалов как по объемам образования, так и по географическому распространению, для стабилизации процесса брожения может использоваться солома пшеницы. Остатки растительной биомассы после сбраживания возвращаются на поля как ценное органическое удобрение.

Рабочая гипотеза исследования может быть сформирована следующим образом: добавление соломы пшеницы позволяет оптимизировать соотношение $\mathrm{C}: \mathrm{N}$ в курином помете и снизить ингибирующее влияние аммонийного азота в технологическом процессе биоконверсии органического вещества.

Идея исследования основывается на выявлении закономерности процесса анаэробного сбраживания в периодическом режиме в условиях с низкой и высокой начальной концентрацией органического вещества смесей куриного помета и соломы пшеницы в их различных массовых пропорциях.

Целью работы является повышение выхода биогаза на биогазовых установках за счет совместного сбраживания куриного помета с экструдированной соломой пшеницы. Для достижения поставленной цели решались следующие задачи: разработан методический подход для проведения исследований; проведен анализ физико-химического состава инокулята и образцов органических материалов; произведено моделирование компонентного состава смеси инокулята и исследуемых образцов органических материалов; экспериментально исследованы показатели выхода биогаза и $\mathrm{CH}_{4}$ в процессе периодического анаэробного сбраживания смесей помета с экструдированной соломой пшеницы.

\section{II. АНАЛИЗ ПОСЛЕДНИХ ИССЛЕДОВАНИЙ}

В работе [1] выход биогаза при моносбраживании куриного помета оценивается как низкий из-за высокого содержания азота и наличия лигноцеллюлозного материала с подстилки. В работе [2] выход биометана из куриного помета оценивается как 173,18 л/кг VS, что ниже выхода биометана из свиного и коровьего навоза (177,36 л/кг VS и 222 л/кг VS соответственно). В работе [3] выход биометана при сбраживании куриного помета оценивается в 508 мл/г VS, в работе [4] - 694,6 мл/г VS, в работе [5] - 183 мл/г VS, а в работе [6] - выход биометана при сбраживании подстилки после содержания бройлеров составил 540 мл/г VS. В работе [7] выход биогаза при сбраживании куриного помета составлял 554 мл/г VS при содержании метана $74 \%$, в работах [8, 9] - 0,53 м³ сут при содержании метана $60 \%$. Как указано в работе [10], выход биогаза при одностадийном сбраживании составляет 517, 551 и 459 мл/г VS при времени гидравлического удерживания 16, 12 и 8 суток соответственно, что превышает выход биогаза при двухстадийном сбраживании (356, 359 и 386 мл/г VS соответственно). Вместе с тем, содержание метана в биогазе при двухстадийном сбраживании выше. В работе [11] утверждается, что чрезвычайно длинная адаптация метаногенов к сбраживанию куриного помета создала уникальные микробные сообщества, в которых метаногены Methanobrevibacter (76\%) и Methanoculleus (18\%) были доминирующими. Соответственно, выход биометана составил 310 +/- 43 мл/г VS, был высокостабильным при уровне аммония 6,2 +/- 0,1 г/л и органической загрузке 2,5 г VS /(л·сутки).

В работе [12] осуществлено сравнение результатов исследования выхода биогаза 
при сбраживании различных субстратов: сыворотки, навоза КРС и свиней, птичьего помета, картофельной шелухи и сточных вод от переработки картофеля. Наибольший выход биометана был получен при сбраживании птичьего помета и отходов картофеля $\left(0,34\right.$ л $\mathrm{CH}^{4} / \Gamma$ ХПК) и навоза КРС $\left(0,33\right.$ л $\left.\mathrm{CH}^{4} / \Gamma \quad \mathrm{X \Pi K}\right) . \quad$ В работе [13] утверждается, что при смешивании куриного помета с кукурузным силосом наибольший выход биогаза составил $46,7 \mathrm{~m}^{3} /$ т субстрата при содержании метана 53,2\% был зафиксирован при соотношении куриного помета к силосу 2:1, в работе [14] - выход биометана при смешивании куриного помета и биомассы Pennisetum purpureum в соотношении 1:1 - 0,27 л/т VS, работе [15] выход биометана при смешивании куриного помета и луговой травы в соотношении 70\%:30\% - 0,33 л/т VS, а куриного помета и соломы пшеницы в соотношении 50\%:50\% 0,34 л/т VS, в работе [16] - при сбраживании смеси куриного помета и рисовой соломы в соотношении $1: 4-0,5738 \mathrm{~m}^{3} / \kappa \Gamma \quad$ VS. Добавление сыворотки в куриный помет, как сказано в работе [17], обеспечивает выход биогаза на уровне 582,0 л/кг VS, биометана 381,2 л/кг VS, хотя при этом возникали проблемы с пенообразованием. В работе [18] сравнивался выход биогаза и биометана при сбраживании куриного помета (590 дм³/кг VS

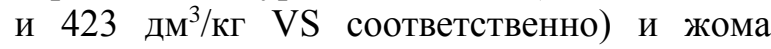

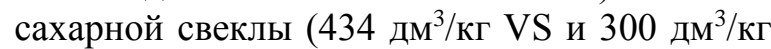
VS соответственно). При этом отмечалось торможение брожения в субстрате с куриным пометом вследствие высокого уровня аммиака. Смесь этих компонентов обеспечивала выход биометана 346 дм $3 /$ кг VS, при этом торможение брожения не наблюдалось. В работе [19] для общего сбраживании рисовой соломы и куриного помета рекомендуется придерживаться скорости органической загрузки 4,8 кг VS/m ${ }^{3}$, при этом выход биогаза составляет 380 л/кг VS. В работе [20] указывается, что общее сбраживание сточных вод тайской рисовой лапши с куриным пометом, рисовой шелухой и 6 г зольной добавки обеспечивает выход биометана на уровне 311,2 мл/г VS при температуре брожения $28-30^{\circ} \mathrm{C}$, а в работе [21] - совместное сбраживание рапсовой соломы с кухонными отходами и утиным пометом в соотношении 50:40:10 при двухфазном анаэробном сбраживании обеспечивало выход биогаза 374,5 л/кг VS при содержании метана 49,7\%.

В работе [22] утверждается, что ферментативная предварительная обработка куриного помета увеличивает выход биогаза примерно на 35\%, в работе [23] - на 6,3-10,4\% (при этом содержание в биогазе сероводорода уменьшается в 1,1-17,4 раза), в работе [1] составляет 835,2 л/кг VS, а в работе [24] добавление к куриному навозу до 10\% древесного биоугля повышает выход биогаза на $42,3 \%$, а концентрацию метана в биогазе на $14,3 \%$, при этом содержание сероводорода уменьшается на 45,6\%. В работе [25] была исследована гипертермическая $\left(70^{\circ} \mathrm{C}\right)$ предварительная обработка куриного помета. В результате выход биометана достигал 518 мл/г VS, что было на 54,6\% выше, чем при контрольном опыте.

Анализ проведенных исследований показывает, что требуется дальнейшее изучение вопроса интенсификации выхода биогаза из субстрата на основе куриного помета, что может быть достигнуто добавлением к нему экструдированной соломы. При этом необходимо определить рациональные граничные соотношения экструдированной соломы и помета, при которых обеспечивается максимальный выход биогаза.

\section{III. МЕТОДИКА ИССЛЕДОВАНИЙ}

Для исследования процесса метанового брожения образцов органических материалов в работе использовался метод периодического сбраживания.

Процесс метанового брожения инициировался на основе смешивания порции образца органического материала с инокулятом (суспензия, содержащая стартовую популяцию жизнеспособных метанообразующих бактерий) в биореакторах, герметизации биореакторов, и поддерживался путем последующего выдерживания образованных смесей в биореакторах при постоянной температуре $36 \pm 1^{\circ}$ С. Для анализа воспроизводимости результатов исследований смеси готовились и сбраживались в 3-х повторах.

Отбор и анализ выделенного биогаза обеспечивался на опытной установке (рис.1), которая включает в себя биореактор и эвдиометр для накопления биогаза. В качестве биореактора использовано стеклянную емкость общим объемом 3 дм $^{3}$. Для 
герметизации газового пространства в верхней части емкости использовано капроновую крышку с штуцером для отвода газа. Штуцер соединен с помощью гибкой трубки из прозрачного ПВХ с алюминиевой трубкой, герметично встроенной в днище неподвижной части эвдиометра - пластикового патрубка диаметром 100 мм с заглушкой. Алюминиевая трубка выходит за край патрубка на 5 мм для предотвращения попадания воды в систему газоотведения. Неподвижную часть эвдиометра установлено стационарно на горизонтальной поверхности и заполнено 5\% водным раствором $\mathrm{NaCl}$, который позволяет избегать потерь биогаза путем абсорбции.
Отбор биогаза на анализ и его отвод выполняется с помощью дополнительной отводной гибкой трубки, на конце которой вмонтирован пробковый газовый кран. Нагрев и контроль температуры воды в емкости, где находится биореактор, организовано с помощью электрического обогревателя, оборудованного терморегулятором. Для интенсивного отвода и равномерного распределения тепла от обогревателя использовано насос погруженного типа, работающий в непрерывном режиме. Измерение температуры производится с помощью лабораторного ртутного термометра.

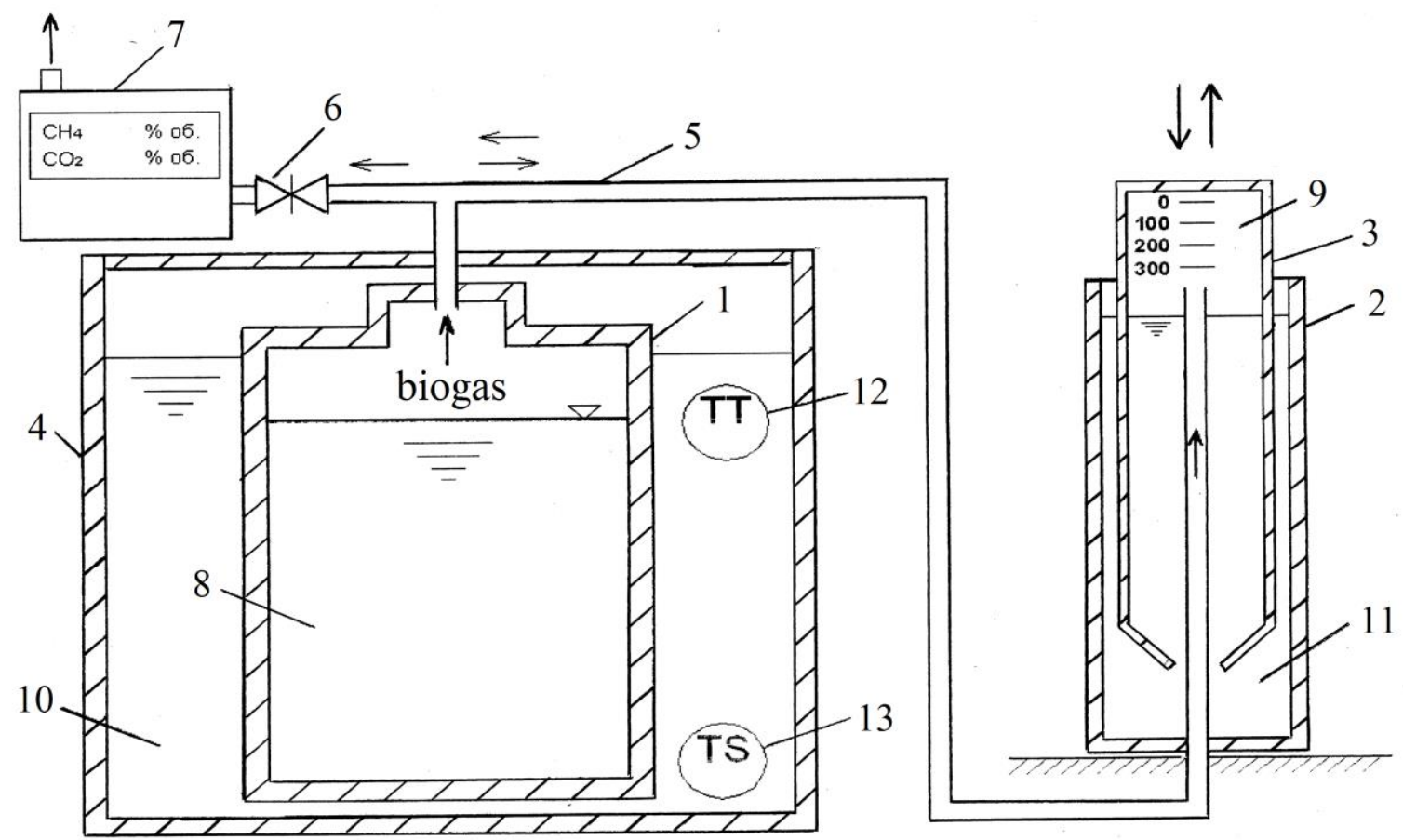

1 - емкость биореактора; 2 - неподвижная часть эвдиометра; 3 - подвижная часть эвдиометра; 4 - емкость с теплоносителем; 5 - трубка ПВХ; 6 - газовый кран; 7 газоанализатор; 8 - рабочая среда биореактора; 9 - внутреннее пространство эвдиометра с биогазом; 10 - теплоноситель (вода); 11 - 5\% водный раствор $\mathrm{NaCl}$; 12 - ртутный термометр; 13 - терморегулятор $\left(\Delta T= \pm 1^{\circ} \mathrm{C}\right)$.

Рис. 1. Схема опытной установки для периодического метанового брожения. ${ }^{1}$

При выделении биогаза за счет повышения давления газа в герметичной системе биореактор-эвдиометр, подвижная часть эвдиометра подымается на высоту, соответствующую определенному значению объема газа на градуированной шкале. Фиксация объема выделенного биогаза осущрествліх 1 дась дискретно, путем визуального считывания с градуированной шкалы эвдиометра. Измеренный объем биогаза приводился к нормальным условиям $\left(273,15 \mathrm{~K} ; 101,3\right.$ кРа). Содержание $\mathrm{CH}_{4}$ в биогазе определялось с помощью портативного цифрового газоанализатора типа Landtec GEM-500.

Для экспериментального исследования в работе использованы следующие виды органических материалов: 
- помет куриный (получен из цехов взрослой птицы бройлеров Белоцерковской птицефабрики);

- гранулы из соломы пшеницы (изготовлены в Национальном университете биоресурсов и природопользования Украины);

- инокулят (получен в лаборатории Института технической теплофизики НАН

Украины).

Согласно результатам анализа химического состава органического вещества предоставленного образца куриного помета, массовое соотношение $\mathrm{C}: \mathrm{N}$ в нем составляет 6,9, C:P - 29,1, C:S - 59,5. Принято считать, что оптимальным значением для роста популяции микроорганизмов является соотношение $\mathrm{C}: \mathrm{N}: \mathrm{P}$ 150:5:1. Соотношение в исследуемом образце куриного помета составляет 29,1:4,2:1 и, таким образом, не является оптимальным, в частности по соотношению $\mathrm{C}: \mathrm{N}$.

Результаты анализа физико-химического состава образцов органических материалов приведены в табл. 1.

Таблица $1^{2}$

Результаты анализа физико-химического состава образцов органических материалов

\begin{tabular}{|c|c|c|c|c|c|}
\hline $\begin{array}{c}\text { Органический } \\
\text { материал } \\
\text { Organic material }\end{array}$ & $\begin{array}{c}\text { Содержание } \\
\text { сухих } \\
\text { веществ (CB), } \\
\text { \% свежей } \\
\text { массы } \\
\text { Total solids } \\
\text { (TS) content, } \\
\text { \% to raw } \\
\text { matter }\end{array}$ & $\begin{array}{c}\text { Содержание } \\
\text { сухого } \\
\text { органического } \\
\text { вещества (COB), } \\
\text { \% CB } \\
\text { Volatile solids } \\
\text { (VS) content, \% } \\
\text { to TS }\end{array}$ & $\begin{array}{c}\text { Содержание } \\
\text { органического } \\
\text { углерода } \\
\left(\mathrm{C}_{\text {орг }}\right), \\
\text { \% COB } \\
\text { Organic carbon } \\
\text { (Corg) content, } \\
\text { \% to VS }\end{array}$ & $\begin{array}{c}\text { Содержание } \\
\text { общего } \\
\text { азота }\left(\mathrm{N}_{\text {общ }}\right) \text {, } \\
\text { \% COB } \\
\text { Total } \\
\text { nitrogen } \\
\left(\mathrm{N}_{\text {tot }}\right) \\
\text { content, \% to } \\
\text { VS }\end{array}$ & $\mathrm{C}: \mathrm{N}$ \\
\hline $\begin{array}{c}\text { Помет куриный } \\
\text { (ПК) } \\
\text { Poultry manure }\end{array}$ & 31,78 & 72,08 & 50,90 & 7,36 & 6,9 \\
\hline $\begin{array}{c}\text { Гранулы соломы } \\
\text { пшеницы (ПСП) } \\
\text { Wheat straw pellets }\end{array}$ & 91,21 & 90,65 & 50,35 & 0,41 & 122,8 \\
\hline $\begin{array}{l}\text { Инокулят } \\
\text { Inoculum }\end{array}$ & 1,99 & 55,00 & - & - & - \\
\hline
\end{tabular}

Для исследования эффективности добавления соломы в куриный помет образованы две группы смесей.

Первая группа смесей создавалась таким образом, чтобы концентрация органического вещества в ней была с одной стороны максимально возможной, и биологически безопасной - с другой. Идея заключалась в образовании такой начальной концентрации азота в смеси инокулята с пометом, которая была бы приближенной к критической, с точки зрения аммонийного ингибирования. При этом концентрация органического вещества и азота не должна быть настолько высокой, что могло бы привести к полному прекращению процесса метанового брожения.

Вторая группа смесей формировалась на основе принципа минимального воздействия на популяции бактерий инокулята с тем, чтобы максимально быстро и полно произвести биодеструкцию входного сырья. Данный принцип положен в основу известных методов исследования биодоступного потенциала выхода $\mathrm{CH}_{4}$ из различных видов сырья, например, в немецком стандарте VDI 4630, где рекомендуется стартовое соотношение массы органического вещества субстрата к органическому веществу инокулята не выше 0,5. В данной работе на основе этих двух подходов образованы: а) смеси инокулята и 100\% помета; б) инокулята, помета 65\% (по массе СОВ) и гранул соломы пшеницы 35\% (по массе СОВ); в) инокулята, помета 35\% (по массе СОВ) и гранул соломы пшеницы 65\% (по массе СОВ) (табл. 2). 
Результаты моделирования состава исследовательских смесей по COB и C:N

\begin{tabular}{|c|c|c|c|c|c|c|}
\hline \multirow{2}{*}{$\begin{array}{l}\text { Показатель } \\
\text { Indicator }\end{array}$} & \multicolumn{6}{|c|}{$\begin{array}{c}\text { Опытная смесь, № } \\
\text { Experimental mixture, № }\end{array}$} \\
\hline & 1 & 2 & 3 & 4 & 5 & 6 \\
\hline $\begin{array}{l}\text { Куриный помет, } \\
\text { доля СОВ в смеси исследуемых органических } \\
\text { материалов, \% } \\
\text { Poultry manure, VS share in the mixture of test } \\
\text { materials, \% }\end{array}$ & $100 \%$ & $65 \%$ & $35 \%$ & $100 \%$ & $65 \%$ & $35 \%$ \\
\hline $\begin{array}{l}\text { Гранула из соломы пшеницы, } \\
\text { доля СОВ в смеси исследуемых органических } \\
\text { материалов, \% } \\
\text { Wheat straw pellets, VS share in the mixture of } \\
\text { test materials, \% }\end{array}$ & $0 \%$ & $35 \%$ & $65 \%$ & $0 \%$ & $35 \%$ & $65 \%$ \\
\hline $\begin{array}{l}\text { Начальная концентрация СОВ смеси } \\
\text { исследуемых органических материалов в } \\
\text { биореакторе, гСОВ/кг } \\
\text { Initial concentration of volatile solids of the } \\
\text { mixture of test materials in bioreactor, gVS/Kg }\end{array}$ & 59 & 58 & 57 & 5 & 5 & 5 \\
\hline $\begin{array}{l}\text { Начальная концентрация } \mathrm{N}_{\text {общ исследуемых }} \\
\text { органических материалов в биореакторе, г } \mathrm{N} / к г \\
\text { Initial concentration of } \mathrm{N}_{\text {tot }} \text { of the mixture of test } \\
\text { materials in bioreactor, gN/Kg }\end{array}$ & 4,34 & 2,86 & 1,67 & 0,40 & 0,26 & 0,15 \\
\hline $\mathrm{C}: \mathrm{N}$ & 6,9 & 10,3 & 17,3 & 6,9 & 10,3 & 17,2 \\
\hline
\end{tabular}

\section{IV. РЕЗУЛЬТАТЫ ИССЛЕДОВАНИЙ}

Представленные исследования отличаются от изложенных в разделе II (Анализ последних исследований) тем, что для увеличения выхода биогаза к куриному помету добавлялись гранулы экструдированной соломы пшеницы.

$$
\text { В результате проведенных }
$$
экспериментальных исследований удалось подтвердить гипотезу о позитивном влиянии на показатели выхода биогаза добавления соломы к куриному помету. Основным результатом исследований является тот факт, что при начальной высокой концентрации органического вещества в реакторе 58-59 гСОВ/кг, наибольшая достигнутая скорость выделения $\mathrm{CH}_{4}$ из смесей помета с соломой повышается до 2 раз, в сравнении с моносбраживанием помета. Данный результат получен впервые и указывает на перспективность добавления пеллетов соломы пшеницы в процессе анаэробного сбраживания куриного помета, в особенности для высоконагружаемых биореакторов.

Длительность периода наблюдений за ходом процесса метанового брожения первой группы опытных смесей составила 66,62 сутокрделя ; ВТорой группы смесей - 32,69 суток. Сравнение кривых зависимости изменения общего выхода биогаза во времени для смесей №1-№3 (рис. 2) показывает, что первые 7-8 суток накопление биогаза происходило тем интенсивнее, чем больше в составе смеси было куриного помета. После 7-8 суток наблюдений, наоборот, накопление биогаза происходило тем быстрее, чем меньше была доля СОВ куриного помета в смеси. При этом объемы накопленного биогаза для всех опытных смесей №1-№3 начали выравниваться, начиная с 42-43 суток наблюдений, а для смесей помета с соломой №2 и №3 - начиная с 34-35 суток.

Сравнение кривых зависимостей изменения общего выхода биогаза по времени для опытных смесей №4-№6 (рис. 3) показывает, что накопление биогаза происходило тем быстрее, чем больше была доля СОВ куриного помета в смеси в течение всего периода наблюдений.

Сравнивая кривые зависимости скорости выхода биогаза для опытных смесей №1-№3 (рис. 4) можно увидеть, что характер их взаимного развития подобен накопительным кривым выхода биогаза, с теми же временными промежутками характерных изменений. 


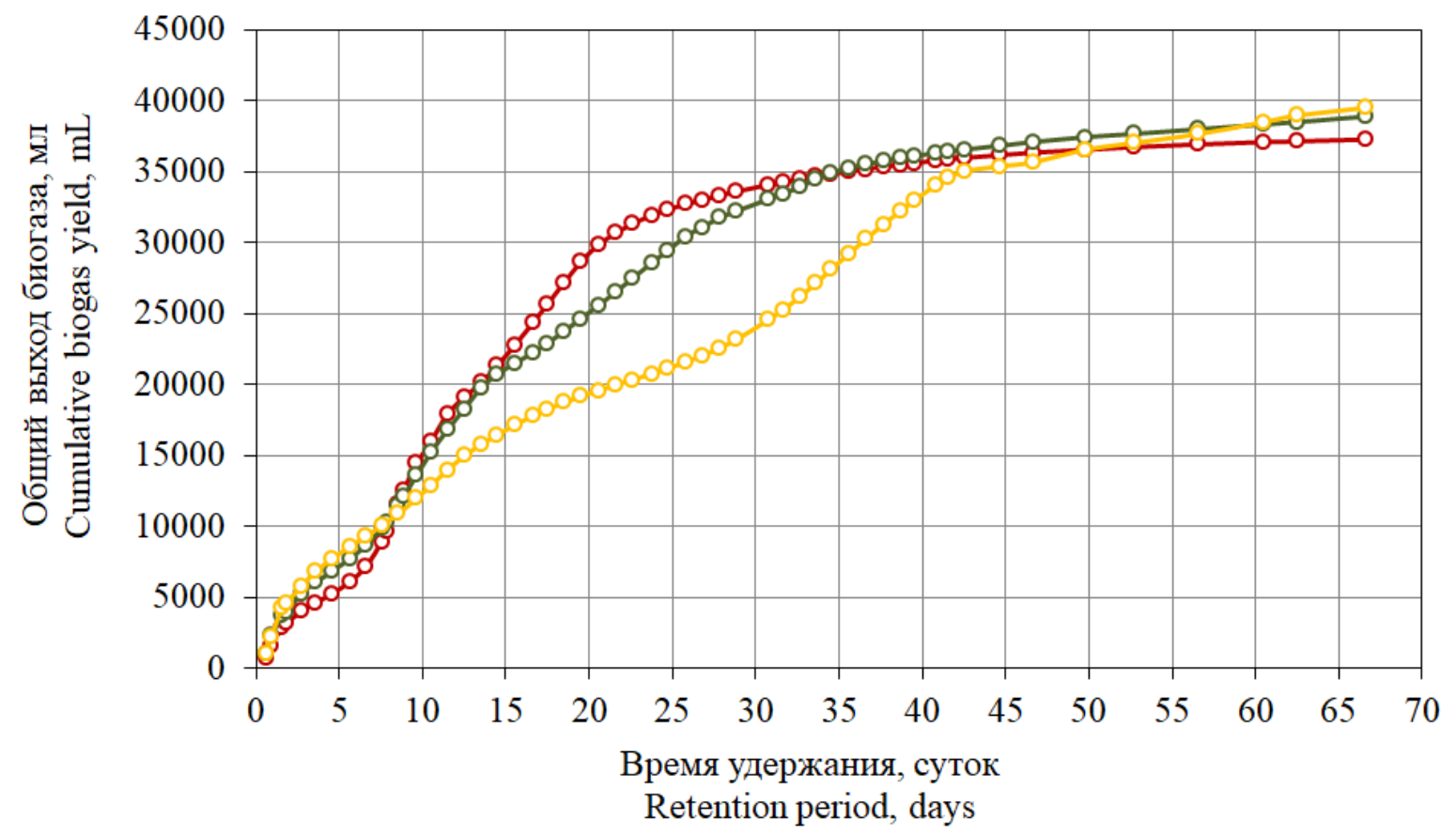

- -СMECЬ №3 - РМ35\%+WSP65\%_57 гСОВ/кг (MIX №3 - PM35\%+WSP65\%_57 gVS/Kg)

- - СMECb №2 - РM65\%+WSP35\%_58 гСОВ/кг (MIX №2 - PM65\%+WSP35\%_58 gVS/Kg)

-О-СMEСЬ №1- РM100\%_59 гСОВ/кг (MIX №1 - PM100\%_59 gVS/Kg)

PM - птичий помет; WSP - гранулы пшеничной соломы

Рис. 2. Общий выход биогаза по времени при сбраживании смесей №1-№3. ${ }^{4}$

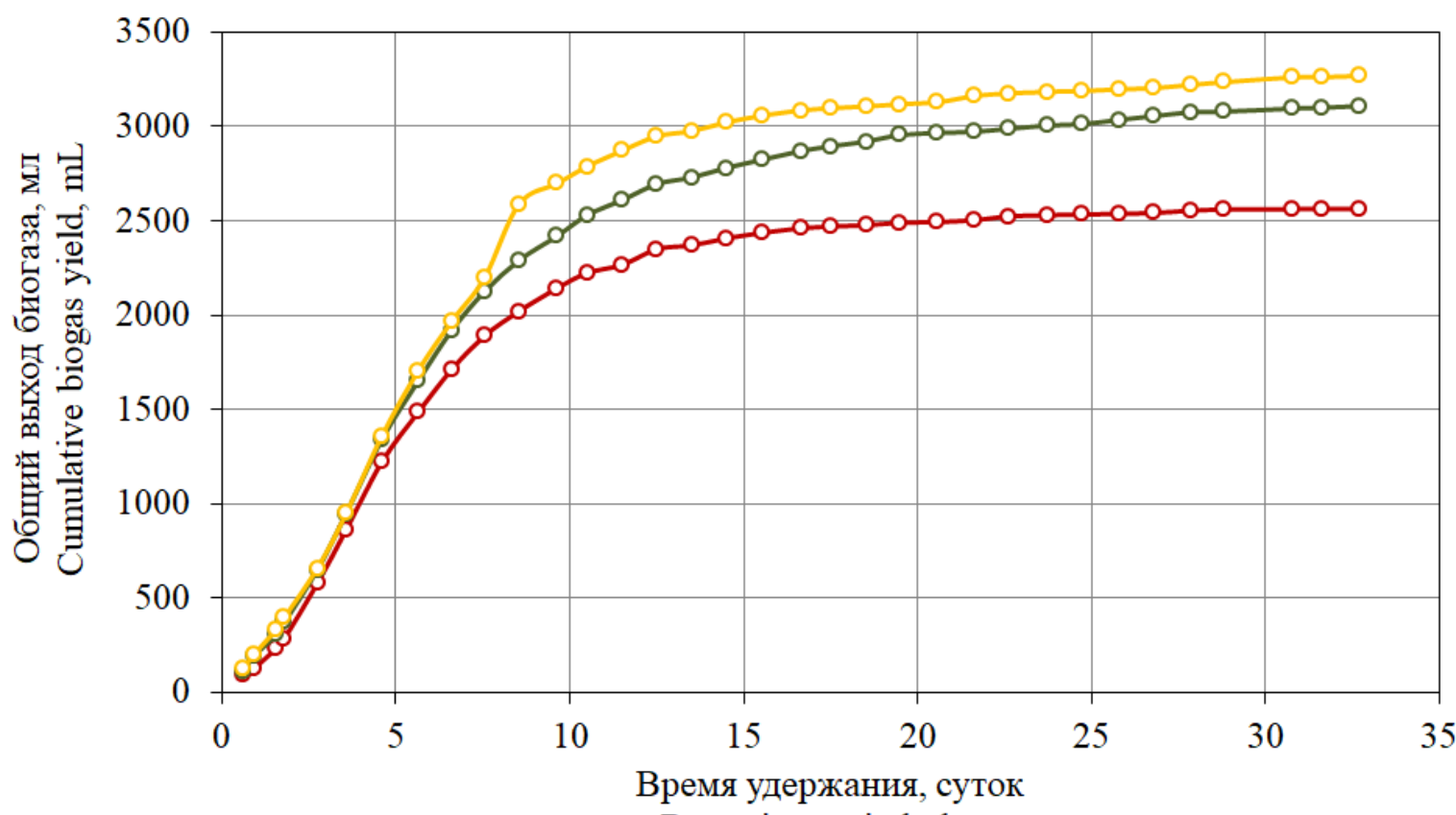

Retention period, days

- - СMECb №6 - PM35\%+WSP65\%_5 гCOB/кг (MIX №6 - PM35\%+WSP65\%_5 gVS/Kg)

- - СMECЬ №5 - PM65\%+WSP35\%_5 гСОВ/кг (MIX №5 - PM65\%+WSP35\%_5 gVS/Kg)

-○-СМEСЬ №4- РM100\%_5 гСОВ/кг (МIX №4 - PM100\%_5 gVS/Kg)

4,5 Appendix 1 PM-птичий помет; WSP - гранульл из пшеничной соломы

Рис. 3. Общий выход биогаза по времени при сбраживании смесей №4-№6. 5 


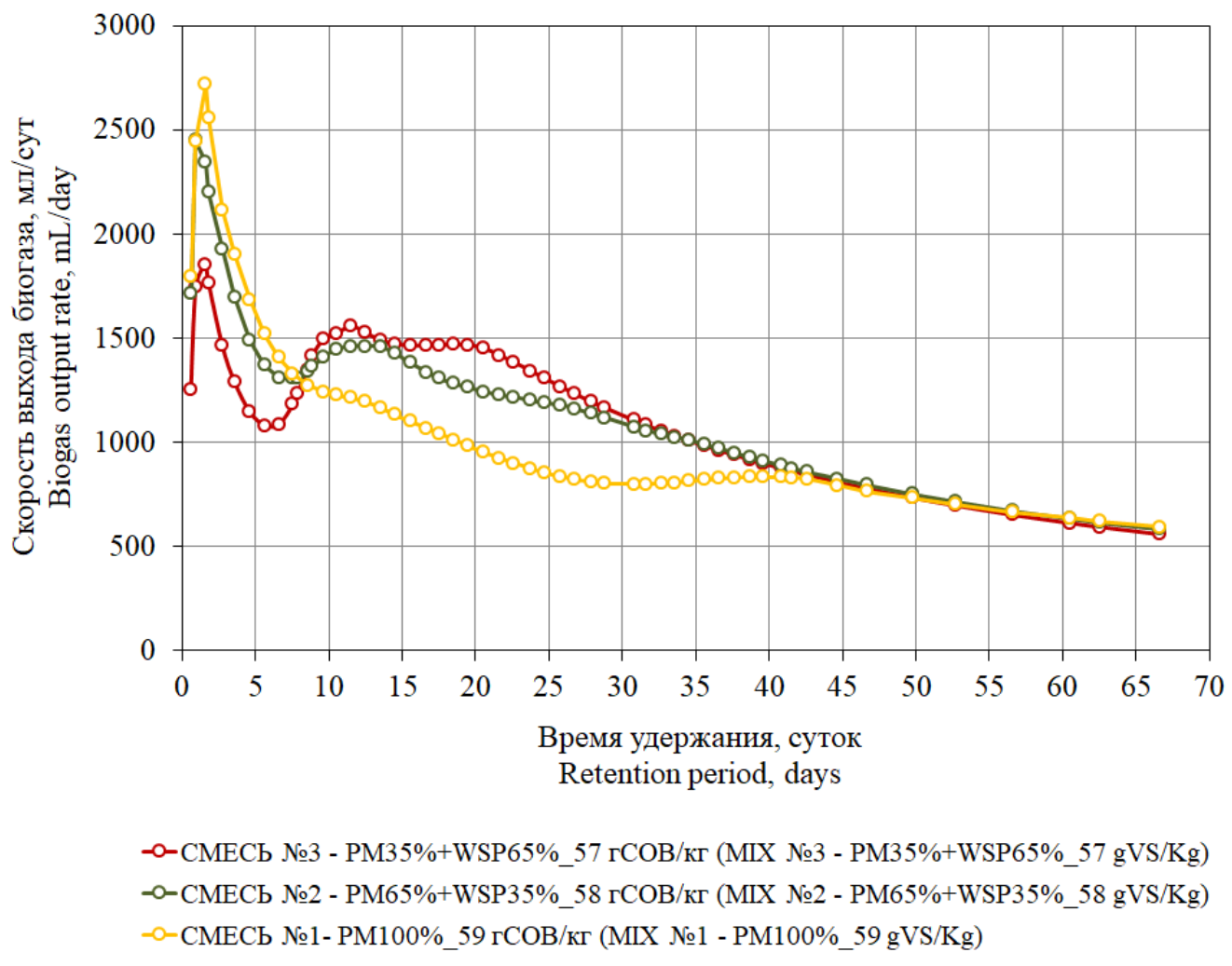

Рис. 4. Скорость выхода биогаза по времени при сбраживании смесей №1-№3. ${ }^{6}$

Из рис. 4 видно, что первые 7-8 суток наиболее стремительно росла скорость выхода биогаза из опытной смеси со $100 \%$ содержанием куриного помета, а наименее интенсивно - с содержанием СОВ помета в смеси $35 \%$. За этот же период были зафиксированы максимальные значения скорости выхода биогаза в течение всего периода наблюдений для всех опытных смесей, у которых была большая доля СОВ помета в смеси.

Аналогично, значения кумулятивной скорости биогаза из всех опытных смесей №1-№3 выровнялись за период 42-43 суток.

Скорость выхода биогаза по времени при сбраживании опытных смесей №4-№6 была тем больше, чем больше была доля СОВ куриного помета, как видно из рис. 5 .

Удельный выход биогаза за периоды наблюдений 66,6 суток и 32,7 суток, соответственно для опытных смесей первой группы №1-№3 и второй группы №4-№6, составил от 279,1 до 507,4 нл/кгСОВ (рис. 6).

Для смеси №1 со $100 \%$ содержанием куриного помета данный показатель составил 426,9-438,5 нл/кгСОВ, для смеси №2 - 446,1-507,4 нл/кгСОВ, для смеси №3 483,2-495,7 нл/кгСОВ, для смеси №4 - 397,0433,9 нл/кгСОВ, для смеси №5 - 400,2-403,1
нл/кгСОВ, для смеси №6 - 279,1-406,7 нл/кгСОВ.

Общим выводом по результатам сопоставления данного показателя для различных смесей является то, что удельный выход биогаза из смесей с высокой начальной концентрацией $\mathrm{COB}$ в биореакторе заметно выше, чем для смесей $\mathrm{c}$ аналогичной пропорцией $\mathrm{COB}$ различных субстратов и низкой начальной концентрацией $\mathrm{COB}$ в биореакторе.

Верхнее значение установленного показателя для смесей №4-№6 является наибольшим для смеси с 100\% помета, на 6,3$7,1 \%$ большим показателя для смесей №5 и №6 с добавлением соломы пшеницы, что указывает на относительно больший потенциал образования биогаза из помета, по сравнению c соломой пшеницы. Данный результат согласуется с исследованиями других авторов и табличными данными, приведенными в различных литературных источниках.

При сбраживании смесей №1-№3 общий выход биогаза за 66,6 суток с опытной смеси №1 из 100\% помета, наоборот, на 13-15\% меньший, по сравнению со смесями с добавлением соломы пшеницы. С учетом того, что на 67 сутки наблюдений 
осуществлялось дальнейшее накопление биогаза для первой группы исследовательских смесей, можно предположить, что за указанный период развития процесса в заданных условиях органическое вещество помета не успело разложиться с образованием биогаза в полной мepe.

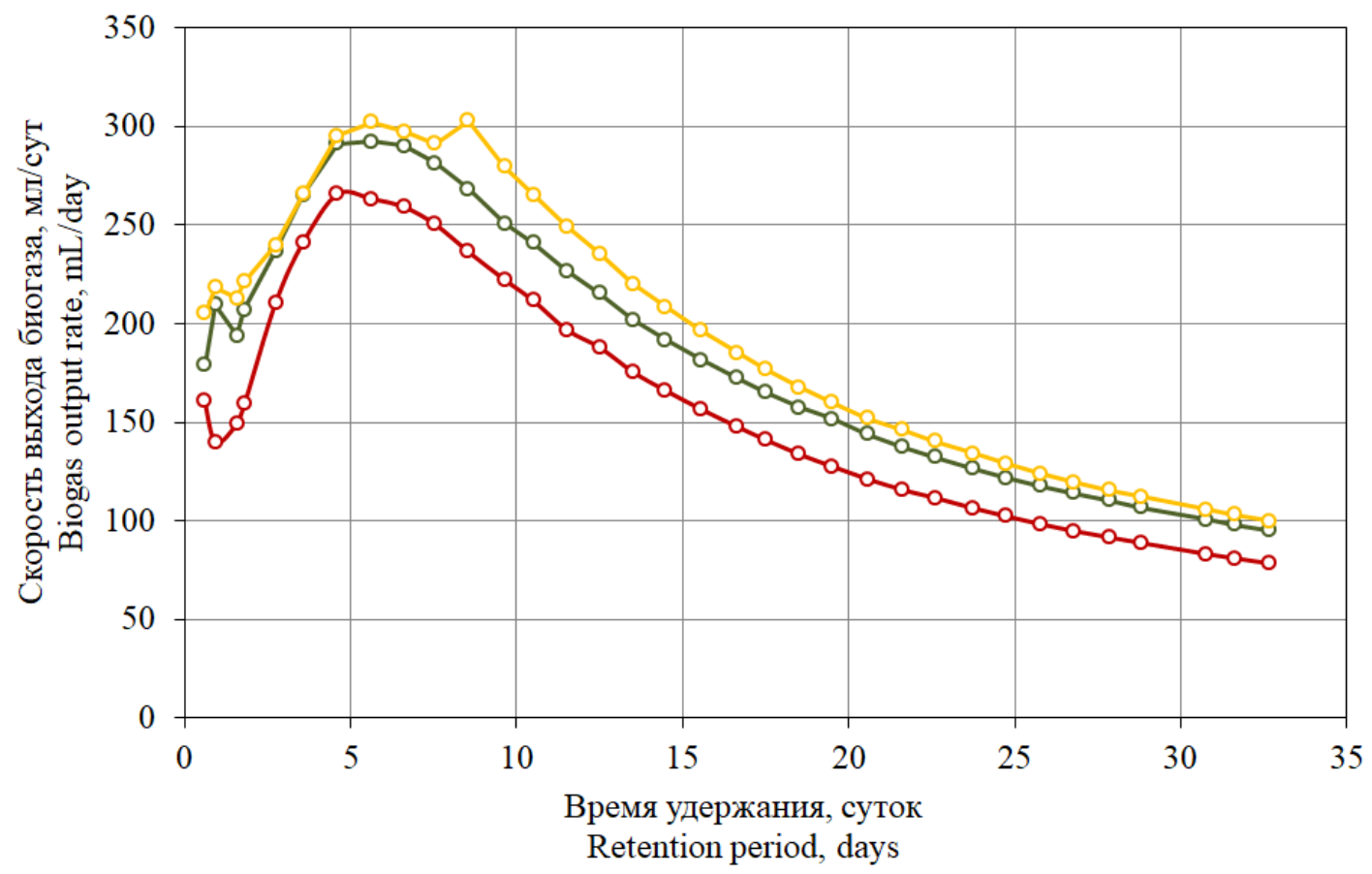

\footnotetext{
- - СMEСЬ №6 - РM35\%+WSP65\%_5 гСОВ/кг (MIX №6 - PM35\%+WSP65\%_5 gVS/Kg) -ం-СMEСЬ №5 - РM65\%+WSP35\%_5 гСОВ/кг (MIX №5 - PM65\%+WSP35\%_5 gVS/Kg)

-O-CMECЬ №4- PM100\%_5 гСОВ/кг (MIX №4 - PM100\%_5 gVS/Kg)
}

Рис. 5. Скорость выхода биогаза по времени при сбраживании смесей №4-№6. ${ }^{7}$

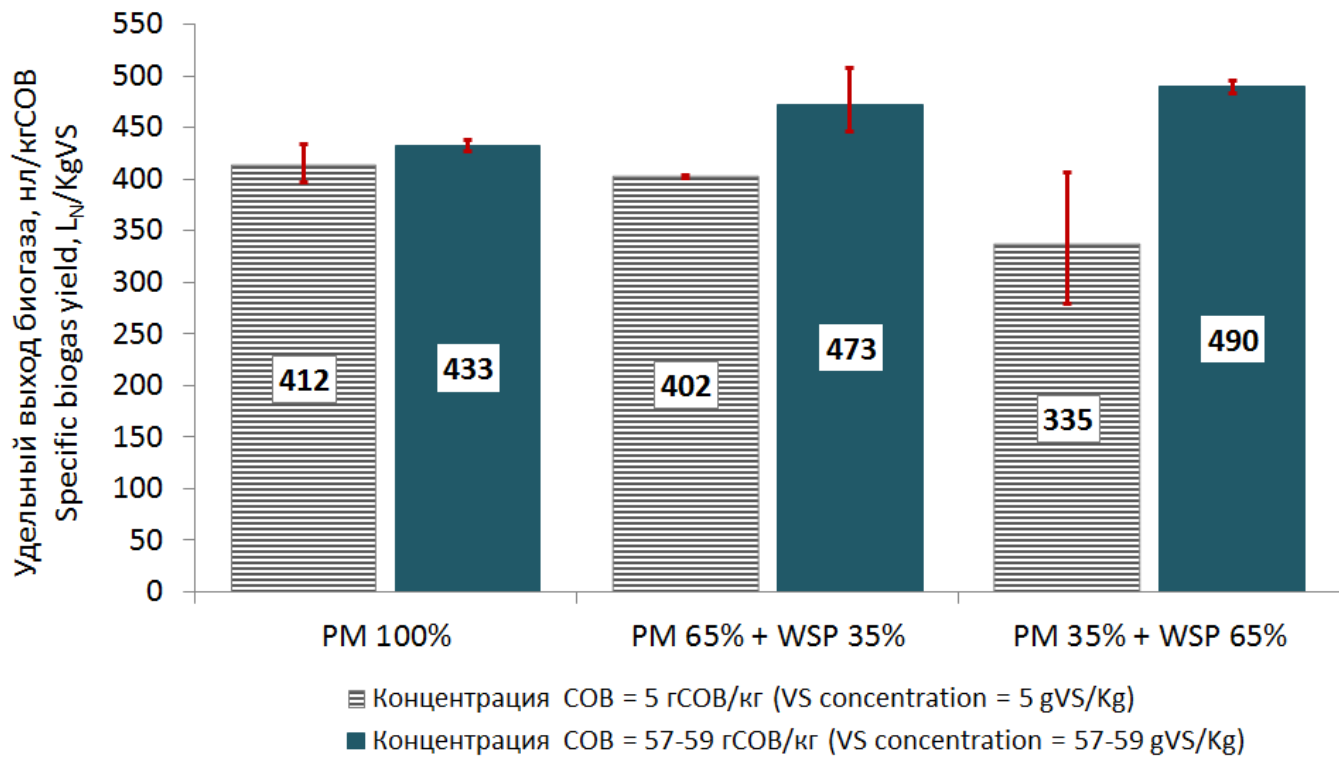

Рис. 6. Удельный выход биогаза за период наблюдений. ${ }^{8}$

Накопленный выход $\mathrm{CH}_{4}$ за весь период наблюдений для опытных смесей №1 составил 262,8-267,9 нлСН $4 /$ кгСОВ, смесей №2 - 269,3-306,6 нлСН 4 /кгСОВ, смесей №3 -
286,9-292,6 нлСН 4 /кгСОВ, смесей №4 251,8-320,2 нлСН ${ }_{4} /$ кгСОВ, смесей №5 275,4-291,2 нлСН $/$ кг СОВ, смесей №6 208,0-297,7 нлСН $/$ кгСОВ (рис. 7). 


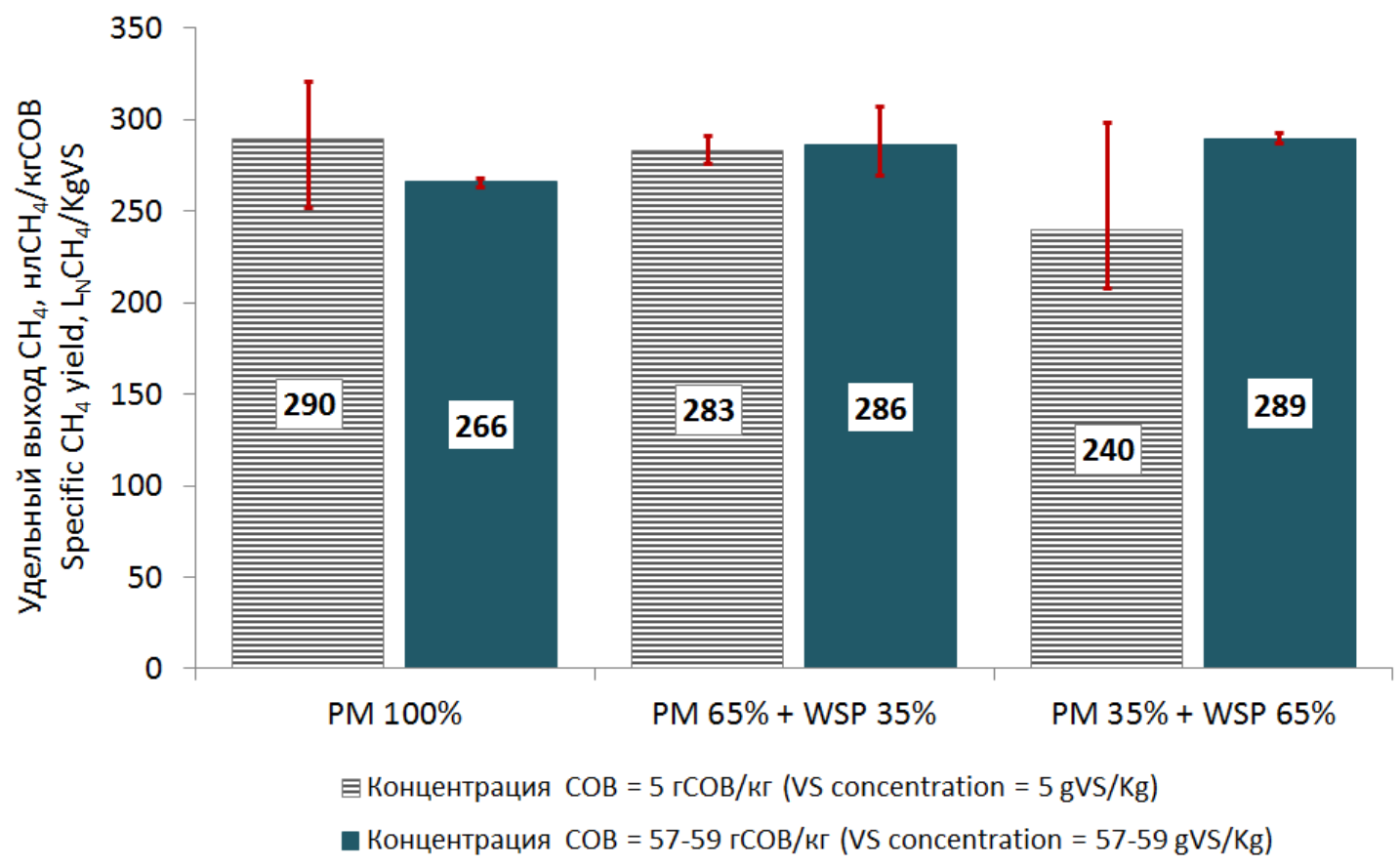

Рис. 7. Удельный выход СН $\mathrm{CH}_{4}$ за период наблюдений. ${ }^{9}$

Наивысшие значения удельного выхода $\mathrm{CH}_{4}$ для всех типов смесей составили 267,9320,2 нлСН $\mathrm{H}_{4} / \kappa \Gamma \mathrm{COB}$. Заметно, что удельный выход $\mathrm{CH}_{4}$ (по максимальным установленным значениям) из куриного помета в смесях №4№6 выше, чем для соломы пшеницы, что коррелируется с данными в литературных источниках. В проведенном исследовании такая разница составила 7-9\%. Напротив, уменьшение доли СОВ куриного помета в смесях №1-№3 привело к увеличению величины удельного накопленного выхода $\mathrm{CH}_{4}$ за период 66,6 суток на 9-14\%.

При дневной загрузке метантенка 20,5 т куриного помета и 3,1 т гранул соломы в полученном биогазе $60,5 \%$ метана, период окупаемости биогазового комплекса будет составлять 4,4 года (рис. 8).

\section{V. ВЫВОДЫ}

1. Разработана новая методика определения рациональных граничных соотношений экструдированной соломы и помета, при которых обеспечивается максимальный выход биогаза. Смешивание помета с соломой в пропорциях $65 \%: 35 \%$ и $35 \%: 65 \%$ по массе СОВ при начальной концентрации СОВ 57-59 гСОВ/кг, позволило увеличить значение наибольшей достигнутой скорости выхода $\mathrm{CH}_{4}$ в пержррдендеском процессе анаэробного сбраживания в 1,6 и 2 раза соответственно по сравнению с контрольным образцом со $100 \%$ содержанием помета.

2. Экспериментально подтверждено, что добавление соломы пшеницы к куриному помету позволяет снизить ингибирующее влияние аммонийного азота в технологическом процессе биоконверсии органического вещества, что обосновывается оптимальным соотношением $\mathrm{C}: \mathrm{N}$ в смеси.

3. Положительный эффект от добавления соломы пшеницы к помету наблюдается в смесях с высокой стартовой концентрацией органического вещества, а следовательно, и высокой стартовой концентрацией азота.

4. На основе экспериментально установленных зависимостей и сравнительного анализа можно рекомендовать солому пшеницы в гранулированном виде в качестве дополнительного субстрата к помету, что позволяет стабилизировать процессы метанового брожения, в частности в высоконагруженных биореакторах, и увеличивать удельную скорость образования биогаза и $\mathrm{CH}_{4}$.

5. В рамках продолжения данной работы на основе предлагаемого научнометодического аппарата целесообразно в зависимости от условий эксплуатации для конкретной биогазовой установки проводить обоснование технологического оптимума доли соломы пшеницы в смеси с пометом. 


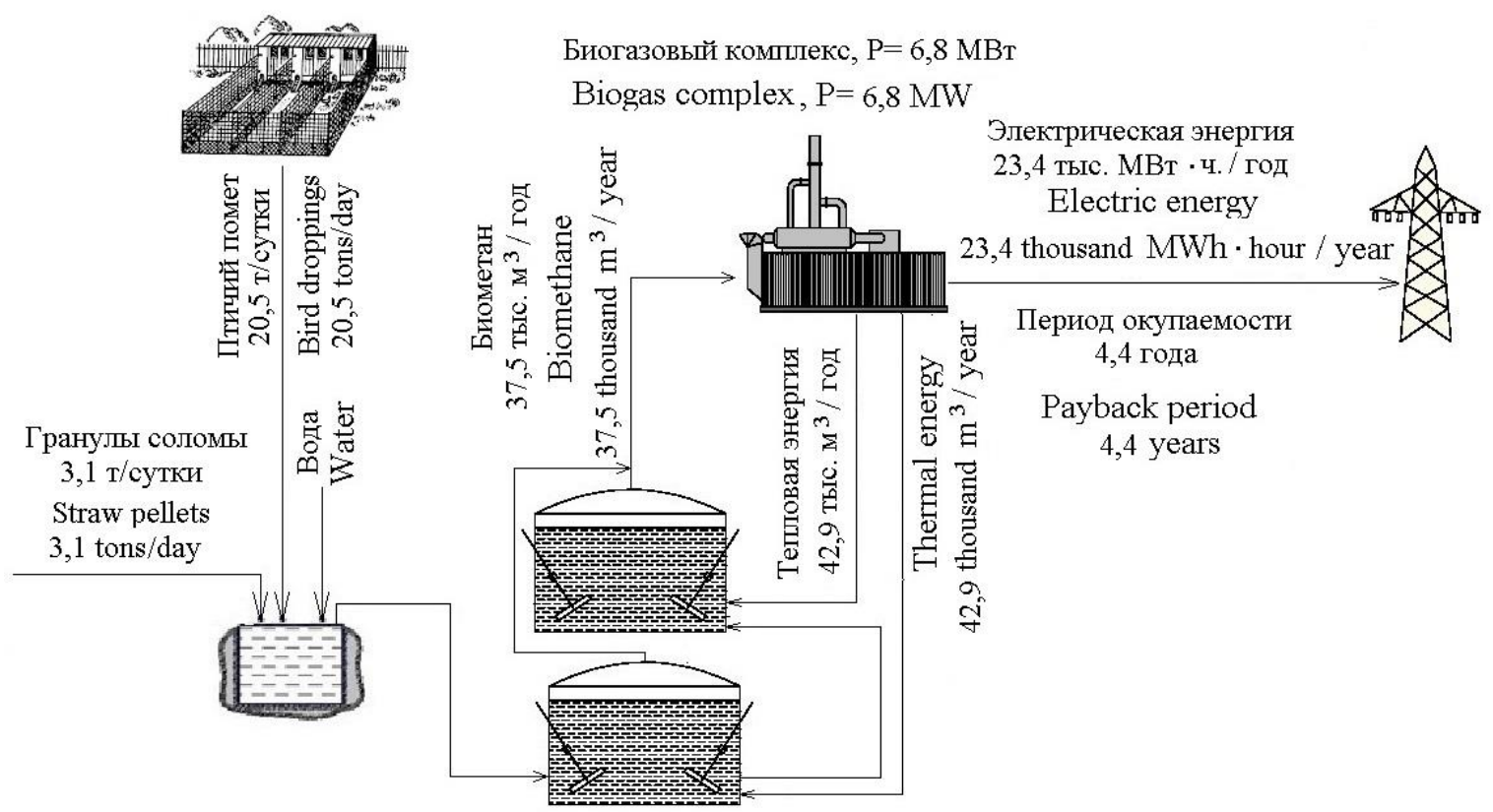
Рис. 8. Схема производства биогаза из куриного помета и гранулированной соломы с
выработкой тепловой и электрической энергии.

\section{Appendix 1}

${ }^{1}$ Fig. 1. Scheme of an experimental plant for batch methane fermentation: 1 - capacity of the bioreactor; 2 - fixed part of the eudiometer; 3 - moving part of the eudiometer; 4 - container with coolant; 5 - PVC tube; 6 - gas cock; 7 - gas analyzer; 8 - working environment of the bioreactor; 9 - internal space of the eudiometer with biogas; 10 - coolant (water); 11 - $5 \%$ aqueous $\mathrm{NaCl}$ solution; 12 - mercury thermometer; 13 - thermostat $\left(\Delta \mathrm{T}= \pm 1^{\circ} \mathrm{C}\right)$.

${ }^{4}$ Fig. 2. Cumulative time yield of biogas during fermentation of mixtures No. 1-No. 3.

${ }^{5}$ Fig. 3. Cumulative time yield of biogas during fermentation of mixtures No. 4-No. 6.

${ }^{6}$ Fig. 4. Cumulative time velocity of biogas during fermentation of mixtures No. 1-No. 3.

${ }^{7}$ Fig. 5. Cumulative time velocity of biogas during fermentation of mixtures No. 4-No. 6.

${ }^{8}$ Fig. 6. Cumulative biogas yield during the observation period.

${ }^{9}$ Fig. 7. Cumulative $\mathrm{CH}_{4}$ output during the observation period.

${ }^{10}$ Fig. 8. Scheme of biogas production from chicken manure and pelleted straw for the production of heat and electricity.

${ }^{2}$ Table 1. Results of the analysis of the physicochemical composition of samples of organic materials.

${ }^{3}$ Table 2. Results of modeling of the composition of the test mixtures for DOM and $\mathrm{C}: \mathrm{N}$.

\section{Библиография (References)}

[1] Bhatnagar, N., Ryan, D., Murphy, R., Enright, A.M. Trace Element Supplementation and
Enzyme Addition to Enhance Biogas Production by Anaerobic Digestion of Chicken Litter. Energies. 2020. Vol. 13, Iss. 13. AN. 3477. doi: 10.3390/en13133477.

[2] Thu, C.T.T., Sommer, S.G., Trach, N.X. Biogas Production from Chicken, Pig and Cow Manure: Influence of Biomass Composition on the Methane Yield. For results: International Conference on Frontiers of Environment, Energy and Bioscience (ICFEEB) (Oct 24-25, 2013, Beijing, China). 2013. P. 462-467.

[3] Jurgutis, L., Slepetiene, A., Volungevicius, J., Amaleviciute-Volunge, K. Biogas Production from Chicken Manure at Different Organic Loading Rates in a Mesophilic Full Scale Anaerobic Digestion Plant. Biomass \& Bioenergy. 2020. Vol. 141. AN. 105693. doi: 10.1016/j.biombioe.2020.105693.

[4] Ware, A., Power, N. Potential of Energy Generation from the Biogas Transformation of Poultry Slaughterhouse By-Products. For results: 23rd European Biomass Conference and Exhibition (EU BC and E) (Jun 01-04 2015, Vienna, Austria), Papers Of The 23rd European Biomass Conference. 2015. P. 98103.

[5] Liu, X.Y., Wang, J.J., Nie, J.M., Wu, N., Yang, F., Yang, R.J. Biogas Production of Chicken Manure by Two-stage Fermentation Process. For results: fourth International Conference on Energy Materials and Environment Engineering (ICEMEE) (Apr 13-15, 2018, Kuala Lumpur, Malaysia). E3S Web of Conferences. 2018. Vol. 38. AN. 01048. doi: 10.1051/e3sconf/20183801048.

[6] Victorin, M., Sanchis-Sebastia, M., Davidsson, 
A., Wallberg, O. Production of Biofuels from Animal Bedding: Biogas or Bioethanol? Influence of Feedstock Composition on The Process Layout. Industrial \& Engineering Chemistry Research. 2019. Vol. 58, Iss. 48. P. 21927-21935. doi: 10.1021/acs.iecr.9b04945.

[7] Dalkilic, K., Ugurlu, A. Biogas Production from Chicken Manure at Different Organic Loading Rates in a Mesophilic-Thermopilic Two Stage Anaerobic System. Journal of Bioscience and Bioengineering. 2015. Vol. 120, Iss. 3. P. 315322. doi: 10.1016/j.jbiosc.2015.01.021.

[8] Garfí, M., Ferrer, M.L., Velo, E., Ferrer, I. Evaluating Benefits of Low-Cost Household Digesters for Rural Andean Communities. Renewable and sustainable energy reviews. 2012. Vol. 16. P. 575-581. doi: 10.1016/j.rser.2011.08.023.

[9] Krishania, M., Kumar, V., Kumar, V.V., Malik, A. Analysis of Different Techniques Used for Improvement of Biomethanation Process: A Review. Fuel. 2013. Vol. 106. P. 1-9. doi: 10.1016/j.fuel.2012.12.007.

[10] Dalkilic, K., Ugurlu, A. Influence of Hydraulic Retention Time and Reactor Configuration During Fermentation of Diluted Chicken Manure. Applied Biochemistry and Biotechnology. 2017. Vol. 181, Iss. 1. P. 157176. doi: 10.1007/s12010-016-2205-6.

[11]. Bi, SJ., Westerholm, M., Hu, WR., Mahdy, A., Dong, TL., Sun, YC., Qiao, W., Dong, RJ. The Metabolic Performance and Microbial Communities of Anaerobic Digestion of Chicken Manure under Stressed Ammonia Condition: A Case Study of a 10-year Successful Biogas Plant. Renewable Energy. 2021. Vol. 167. P. 644-651. doi: 10.1016/j.renene.2020.11.133.

[12] Dareioti, M.A., Vgenis, T.T., Vavouraki, A.I., Kornaros, M. Assessment of Metane Production from Typical Western Greece AgroIndustrial Wastes. For results: 13th International Conference on Environmental Science and Technology (CEST) (Sep 05-07, 2013, Athens, Greece), Proceedings of the International Conference on Environmental Science and Technology. 2013.

[13] Johari, S.A.M., Aqsha, A., Osman, N.B., Shamsudin, M.R., Ameen, M., Dol, S.S. Enhancing Biogas Production in Anaerobic CoDigestion of Fresh Chicken Manure with Corn Stover at Laboratory Scale. SN Applied Sciences. 2020. Vol. 2, Iss. 7. AN. 1260. doi: 10.1007/s42452-020-3063-y.

[14] Wilawan, W., Pholchan, P., Aggarangsi, P. Biogas Production from Co-digestion of Pennisetum Pururem cv. Pakchong 1 Grass and Layer Chicken Manure Using Completely Stirred Tank. For results: International Conference on Alternative Energy in Developing Countries and Emerging Economies (AEDCEE) (May 30-31, 2013, Bangkok, Thailand). Energy Procedia. 2014.
Vol. 52. P. 216-222. doi: 10.1016/j.egypro.2014.07.072.

[15] Rahman, M.A., Moller, H.B., Saha, C.K., Alam, M.M., Wahid, R., Feng, L. Optimal Ratio for Anaerobic Co-Digestion of Poultry Droppings and Lignocellulosic-rich Substrates for Enhanced Biogas Production. Energy for Sustainable Development. 2017. Vol. 39. P. 5966. doi: 10.1016/j.esd.2017.04.004.

[16] Srichat, A., Suntivarakorn, R., Winitchai, S. Biogas Production Fom Broiler Chicken Manure Using Continuous Stirred Tank Reactor System. For results: International Conference on Agricultural, Food and Biological Engineering (ICAFBE) (2012, Guangzhou, China), Journal of Biobased Materials and Bioenergy. 2013. Vol. 7, Iss. 2, SI. P. 247-251. doi: 10.1166/jbmb.2013.1321.

[17] Ramos-Suarez, J.L., Vargas-Avendano, C.L., Mata-Gonzalez, J., Camacho-Perez, A. Evaluation of Poultry Manure and Goat Cheese Whey Anaerobic Co-Digestion. Spanish Journal of Agricultural Research. 2019. Vol. 17, Iss. 2. e0302. doi: 10.5424/sjar/2019172-14577.

[18] Borowski, S., Kucner, M., Czyzowska, A., Berlowska, J. Co-Digestion of Poultry Manure and Residues from Enzymatic Saccharification and Dewatering of Sugar Beet Pulp. Renewable Energy. 2016. Vol. 99. P. 492-500. doi: 10.1016/j.renene.2016.07.046.

[19] Mei, ZL., Liu, XF., Huang, XB., Li, D., Yan, ZY., Yuan, YX., Huang, YJ. Anaerobic Mesophilic Codigestion of Rice Straw and Chicken Manure: Effects of Organic Loading Rate On Process Stability and Performance. Applied Biochemistry and Biotechnology. 2016. Vol. 179, Iss. 5. P. 846-862. doi: 10.1007/s12010-016-2035-6.

[20] Jijai, S., Muleng, S., Noynoo, L., Siripatana, C. Kinetic Model of Biogas Production From CoDigestion of Thai Rice Noodle Wastewater with Rice Husk and Different Type of Manure with Ash Supplement. For results: International Conference on Sustainable Energy and Green Technology (SEGT) (Dec 11-14, 2019, Bangkok, Thailand). IOP Conference Series-Earth and Environmental Science. 2020. Vol. 463. AN. 012008. doi: 10.1088/1755-1315/463/1/012008.

[21] Wang, CQ., Hong, F., Lu, Y., Li, XN., Liu, HM. Improved Biogas Production and Biodegradation of Oilseed Rape Straw by Using Kitchen Waste and Duck Droppings as Co-Substrates in Two-Phase Anaerobic Digestion. Plos One. 2017. Vol. 12, Iss. 8. AN. e0182361. doi: 10.1371/journal.pone.0182361.

[22] Kucuker, M.A., Demirel, B., Onay, T.T. Enhanced Biogas Production from Chicken Manure via Enzymatic Pretreatment. Journal Of Material Cycles And Waste Managenent. 2020. Vol. 22, Iss. 5. P. 1521-1528. doi: 10.1007/s10163-020-01039-w. 
[23] Rubezius, M., Bleizgys, R., Venslauskas, K., Navickas, K. Influence Of Biological Pretreatment of Poultry Manure on Biochemical Methane Potential and Ammonia Emission. Biomass \& Bioenergy. 2020. 142. AN. 105815. doi: 10.1016/j.biombioe.2020.105815.

[24] Kolodynskij, V., Baltrenas, P., Dobele, G. Experimental Research of Biogas Production by Using a Three-Stage Semi-Continuous Bioreactor with Modified Mixer. Energy Sources, Part A: Recovery, Utilization, and

\section{Сведения об авторах.}

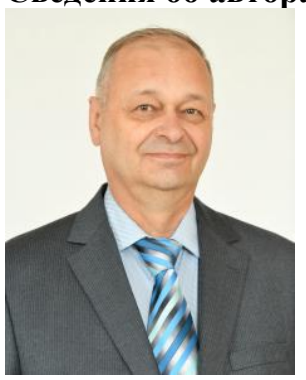

Полищук Виктор

Николаевич. Национальный университет биоресурсов и природопользования Украины, кафедра охраны труда и биотехнических систем в животноводстве, доктор технических наук, профессор. Основная область исследований: технологии и технические средства производства биотоплива.

E-mail:

polischuk.v.m@gmail.com

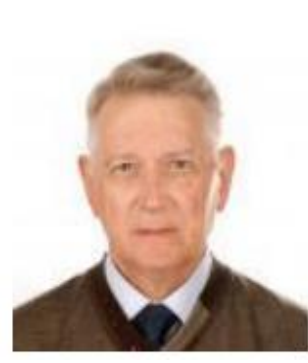

Заблодский Николай Николаевич. Национальный университет биоресурсов и природопользования Украины. Заместитель директора института энергетики, автоматики и энергосбережения, доктор технических наук, профессор. Основная область исследований: технологии конверсии биомассы в высококачественный биогаз по сокращенной ферментации под воздействием электромагнитного поля, переработка побочных продуктов птицеводства в топливо, биологические корма и удобрения.

E-mail: zablodskiynn@ gmail.com

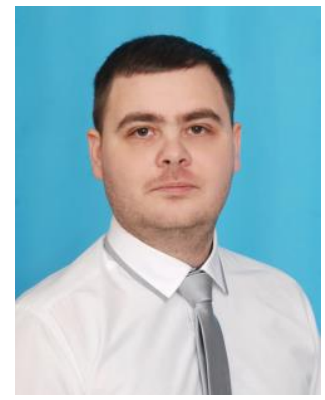

Давиденко Тарас Сергеевич.

Национальный университет биоресурсов

природопользования Украины, кафедра автоматики и робототехнических систем имени академика И.И. Мартыненка, аспирант. Основная область исследований: автоматизированный контроль технологических процессов.

E-mail:

davidenkotaras009@gmail.com
Environmental Effects. 2020. doi: 10.1080/15567036.2020.1772909.

[25] Yin, D.-M., Qiao, W., Negri, C., Adani, F., Fan, R., Dong, R.-J. Enhancing Hyper-Thermophilic Hydrolysis Pre-Treatment of Chicken Manure for Biogas Production by In-Situ Gas Phase Ammonia Stripping. Bioresourse Technology. 2019. Vol. 287. AN. 121470. doi: 10.1016/j.biortech.2019.121470.

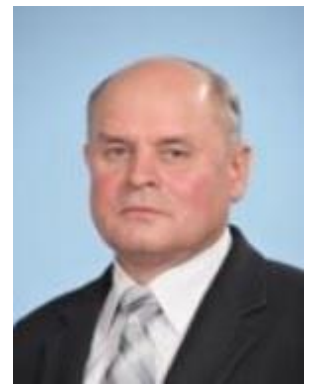

Шворов Сергей Андреевич. Национальный университет биоресурсов природопользования

Украины, кафедра автоматики и робототехнических систем имени академика И.И. Мартыненка, доктор технических наук, профессор. Основная область исследований: создание робототехнических систем для сбора и переработки органического сырья.

E-mail: sosdok@nubip.edu.ua

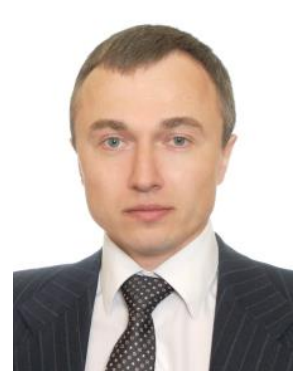

Кучерук Петр Петрович Институт технической теплофизики НАН Украины, старший научный сотрудник отдела теплофизических проблем биоэнергетики.

Кандидат технических наук (PhD).

Основная область исследований: технологии и экономика производства и энергетической утилизации биогаза, оценка воздействия парниковых газов на атмосферу, переработка отходов АПК.

E-mail: pitku@i.ua

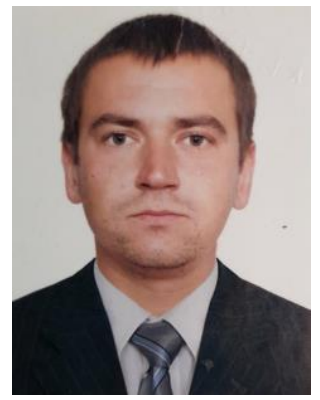

Дворник

Евгений

Алексеевич. Национальный университет биоресурсов и природопользования Украины, кафедра технического сервиса и инженерного менеджмента имени Н.П. Момотенка, аспирант. Основное направление исследований: технологии и технические средства производства биотоплива.

E-mail:

dvornykevgen@gmail.com 